\section{SIZING A PARABOLIC TROUGH COLLECTOR FOR A MICRO SOLAR ORGANIC RANKINE CYCLE}

\author{
Choi Yun Chai, Hyung-chul Jung*
}

Department of Mechanical Engineering, Faculty of Engineering and Science, Curtin University Sarawak, CDT 250, 98009 Miri Sarawak, Malaysia
Article history

Received

12 December 2017

Received in revised form

11 October 2018

Accepted

1 November 2018

Published online

18 February 2019

*Corresponding author jung.hc@curtin.edu.my

\section{Graphical abstract}

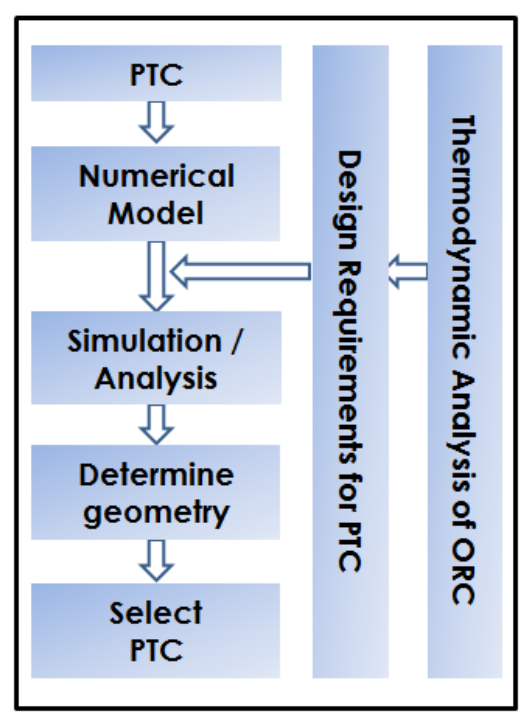

\begin{abstract}
There are many remote villages in Malaysia that are not connected to an electric grid, and are dependent on expensive diesel generator sets (gensets) in their daily activities. Malaysia, a tropical country, has the potential to promote solar power generation in these isolated areas. The organic Rankine cycle (ORC) using solar thermal energy as the heat source could be an attractive approach to off-grid power generation. In this study, a $1 \mathrm{kWe}$ solar ORC with a parabolic trough collector (PTC) is proposed. The ORC utilizes R245fa as the working fluid and Therminol VP1 as the heat transfer medium between the PTC and ORC. Thermodynamic analysis of the ORC is performed, predicting the performance of the ORC and the operating conditions of the PTC. Based on the design requirements of the PTC from the power cycle analysis, process of sizing the PTC is conducted via a numerical model. Seven sets of heat collector elements (HCE) are examined. The effects of absorber tube material, selective coating on the outer surface of the absorber tube, and the absorber tube diameter on the PTC performance are presented. Simulation results show that HCE with $6 \mathrm{~mm}$ of SS316L absorber tube, enclosed with $11 \mathrm{~mm}$ of Pyrex borosilicate glass tube, has the highest collector efficiency of $62.25 \%$. The receiver length required is 8.05 $\mathrm{m}$ and the aperture width of the collector is $3.54 \mathrm{~m}$. Further study is recommended to select a thermal storage system for night-time operation of the ORC.
\end{abstract}

Keywords: Parabolic trough solar collector, solar organic Rankine cycle, heat collector element, modeling, working fluid

\begin{abstract}
Abstrak
Terdapat banyak kampung-kampung terpencil di Malaysia yang tidak disambungkan ke grid elektrik untuk, dan bergantung kepada set generator diesel mahal (gensets) dalam aktiviti-aktiviti harian mereka. Malaysia, sebuah negara tropika, mempunyai potensi untuk menggalakkan penjanaan tenaga suria di kawasan-kawasan terpencil. Organik Rankine kitaran (ORC) menggunakan tenaga terma Suria sebagai sumber haba boleh menjadi satu pendekatan yang menarik untuk penjanaan kuasa luar grid. Dalam kajian ini, satu kWe 1 ORC solar dengan Pemungut melalui parabolic (PTC) adalah dicadangkan. ORC yang menggunakan R245fa sebagai bendalir kerja dan Therminol VPl sebagai medium pemindahan haba antara PTC dan ORC. Analisis termodinamik ORC yang dilakukan, meramalkan prestasi ORC itu dan syarat-syarat operasi dibuat. Mengikut keperluan Reka bentuk yang dibuat daripada analisis kitaran kuasa, proses saiz dibuat akan dilakukan melalui model berangka. Tujuh set elemen Pemungut haba (HCE) akan diperiksa. Kesan-kesan bahan tiub absorber, lapisan terpilih di permukaan luar tiub absorber, dan diameter tiub absorber prestasi PTC dimuatkan. Keputusan simulasi menunjukkan bahawa HCE dengan 6 mm SS316L tiub absorber, disertakan bersama dengan $11 \mathrm{~mm}$ tiub borosilicate kaca Pyrex,
\end{abstract}


mempunyai kecekapan pengumpul tertinggi sebanyak $62.25 \%$. Panjang penerima yang diperlukan adalah $8.05 \mathrm{~m}$ dan lebar aperture pengumpul ini ialah $3.54 \mathrm{~m}$. Pelajaran adalah disyorkan untuk memilih satu sistem Menyimpan haba untuk operasi ORC di waktu malam.

Kata kunci: Pengumpul Suria Parabolic melalui kitaran Rankine organik solar haba Pemungut elemen, permodelan, bendalir kerja

\subsection{INTRODUCTION}

In recent years, fossil fuel has been depleting at a rapid rate due to the increase in world population [1]. In addition, concerns over the impact of fossil fuels on the environment and public health have been raised. As such, renewable energy like solar has attracted more attention than ever before. The first solar power plant with a single axis parabolic trough collector (PTC) was installed in California in 1984 [2]. The size of the plant increased to 9 PTCs from 1985 to 1991 [3]. Concentrated solar power (CSP) plant has become one of the main renewable energy solutions for electricity generation in tropical countries [4].

An organic Rankine cycle (ORC) system is a proven technology to produce electrical energy from low-grade heat sources such as lowtemperature geothermal fluids, low-grade industrial waste heat, biomass, and solar thermal energy. An ORC is similar to a traditional steam Rankine cycle; however, instead of using water, it uses refrigerants with relatively low boiling points as the working fluid. Therefore, an ORC can operate at lower temperatures, resulting in its simple structure, low operational and maintenance cost, and possibility for a micro power generation system. R245fa is described as an efficient working fluid for an ORC in terms of high efficiency, availability, cost, safety, and low global warming potential [5]. The fluid also yields a lower swept volume for an ORC expander, reducing the size of expander [6].

Studies on the ORC system coupled with PTC have been reported. Desai et al. [4] presented a thermo-economic analysis for solar ORCs using PTC and linear Fresnel collector. They showed that the system with PTC achieved higher efficiency than Fresnel reflector. Sait et al. [7] reported that PTC achieved higher efficiency in the optical capture of solar radiation than Fresnel reflector arrays. Wang et al. [8] performed an off-design analysis on a solarpowered ORC thermal system with a compound parabolic trough. They found that the net power output and average exergy increase with the decrease in environmental temperature. Quoilin et al. [6] developed a model for optimization of a lowcost solar ORC for remote power generation, and evaluated the performance of the system with different working fluids. They proposed that the most efficient working fluid for the system is Sokatherm; but in terms of economic benefit, R245fa is a better option. A small-scale off-grid distributed ORC system was proposed by Orosz et al. [9]. Their experimental results showed that the prototype ORC achieved electricity production with an efficiency of $6 \%$. In a similar study, Pikra et al. [10] presented a small-scale CSP coupled with an ORC in a remote area of Indonesia. They suggested a conceptual $10 \mathrm{kWe}$ small-scale power plant system. The entire plant showed a thermal efficiency of $10.63 \%$. Taccani et al. [11] carried out an experimental test on a $2 \mathrm{~kW}_{\mathrm{e}}$ small-scale solar ORC prototype coupled with a 98 $\mathrm{m}^{2}$ solar field.

Numerical models were developed to examine the performance of ORC power generation system. Orosz et al. [12] developed a solar organic Rankine economic (SORCE) model. They reported that the solar ORC approach is more cost-effective than diesel gensets, with a low cost of $\$ 0.25 / \mathrm{kWh}$. A thermodynamic performance assessment on an integrated geothermal-powered ORC and PTC system was performed by Cakici et al. [13]. They found that the electrical efficiency rises as the collector area increases. They also reported that power generation with the integrated ORC system is more efficient compared to a sole ORC system. A numerical simulation was conducted by Borunda ef al. [14] on PolyTrough 1200 Base Module PTC to investigate the configuration proposed in a general solar thermal power plant. They found that the higher the solar fraction, the lower the energy and exergy efficiencies of the thermal storage systems.

Modeling of PTC using different software was also reported. Forristall [15] presented a detailed heat transfer, and modeling of PTC in one-dimensional and two-dimensional energy balance approaches. Ghasemi and Ranjbar [16] presented a thermal performance analysis of solar PTC using Computational Fluid Dynamics (CFD) commercial code. They showed that the higher volume fraction of particles resulted in higher Nusselt number which increased the volume concentration of nanoparticles, improving the thermal performance of the entire system. 
Over 8,7000 households in 300 isolated villages in the remote rural areas of Sarawak, Malaysia are not connected to the main electricity grid due to the mountainous and challenging terrain of the areas [17]. They depend on the expensive, noisy and polluting diesel gensets that only supply electricity for a few hours at night. Therefore, there is a high demand for a reliable, continuous power supply is in these remote villages.

Malaysia, a tropical country, is located in the second largest solar radiation region on earth; has the potential to promote the use of solar energy. The intensity of solar irradiation is one of the key factors affecting the performance of PTC in power generation. Malaysia receives sunlight during the day time with annual solar radiation of $4.21 \mathrm{kWh} / \mathrm{m}^{2}$ to $5.56 \mathrm{kWh} / \mathrm{m}^{2}$ [18]. Hence, building $1 \mathrm{kWe}$ distributed solar ORC system powered by PTC would be beneficial for remote villages in rural communities.

The main barrier to the development of commercial micro-scale ORC is reducing its construction cost. Reduction of the cost may be achieved by using off-the-shelf components available from refrigeration or air-conditioning market. PTC can also be purchased from manufacturers through a proper selection process. In this paper, the selection process of PTC for a solar ORC is described by identifying the effects of PTC fluid temperature and flow on its efficiency, and the heat absorption and loss. The size of a PTC for a $1 \mathrm{~kW} e$ solar ORC is also determined.

\subsection{METHODOLOGY}

The proposed ORC powered by solar thermal energy is shown in Figure 1(a). The corresponding temperature and entropy diagram is depicted in Figure $1(b)$. The ORC consists of an evaporator, an expander and generator set, an air-cooled condenser (ACC), and a feed pump. R245fa was used as the working fluid of the ORC. A PTC was connected to the ORC to provide solar energy. The heat transfer fluid (HTF) was thermal oil, Therminol VP1. Thermal storage was not considered in this study. The PTC collects solar energy and raises the temperature of the oil passing through the PTC. The heated oil transfers heat to the working fluid in the evaporator. The high pressure, high temperature vapour fluid at the outlet of the evaporator enters the expander, and turns the expander connected to the generator. The low temperature vapour fluid at the exit of the expander flows through the ACC, and is converted into liquid fluid. The feed pump delivers the liquid to the evaporator, completing one working cycle.

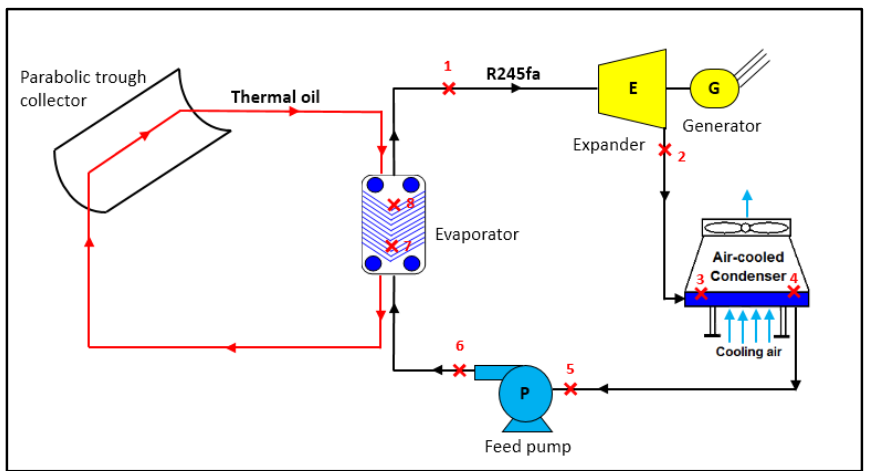

(a)

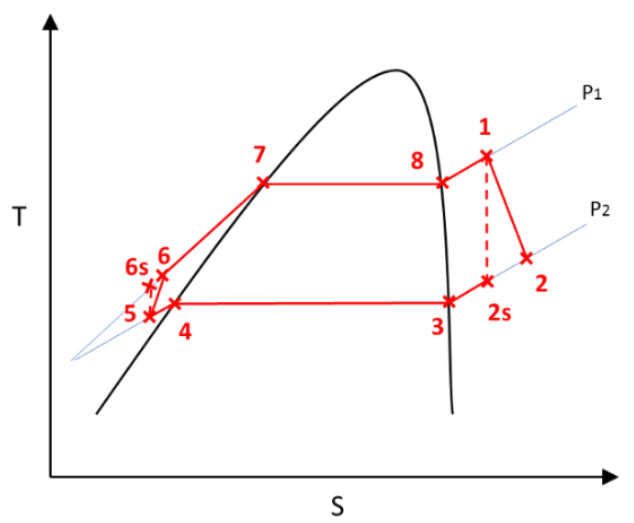

(b)

Figure 1 (a) Schematic of a solar ORC system with PTC and (b) Temperature-entropy (T-s) diagram for the ORC

\subsection{The Solar ORC}

\subsubsection{The Evaporator}

Heat transfer between thermal oil and R245fa in the evaporator was represented by Equation 1. A pinch point temperature difference of $5^{\circ} \mathrm{C}$, a typical value recommended by researchers for a liquid to liquid heat exchanger, was applied to the evaporator as shown in Equations 2 and 3.

$$
\begin{gathered}
\dot{m}_{\text {oil }} C_{p}\left(T_{\text {oil_out }}-T_{\text {oil_in }}\right)=\dot{m}_{W F}\left(h_{1}-h_{6}\right) \\
\Delta T_{p p_{-} e v a}=T_{p p_{-} e v a}-T_{\text {sat_vapor }} \\
T_{p p_{\_} \text {eva }}=\left(\frac{T_{\text {oil_out }}-T_{\text {oil_in }}}{\dot{Q}_{\text {oil }}}\right)\left[\dot{m}_{W F}\left(h_{7}-h_{6}\right)\right]+T_{\text {oil_in }}
\end{gathered}
$$

where $\dot{m}$ is the mass flow rate $(\mathrm{kg} / \mathrm{s}), C_{p}$ is the specific heat capacity $(\mathrm{kJ} / \mathrm{kg} \cdot \mathrm{K}), T$ is the temperature $\left({ }^{\circ} \mathrm{C}\right), h$ is the enthalpy $(\mathrm{kJ} / \mathrm{kg}), \Delta T_{p p}$ is the pinch point difference $\left({ }^{\circ} \mathrm{C}\right), T_{p \mathrm{p}}$ is the pinch point temperature $\left({ }^{\circ} \mathrm{C}\right)$, and $\dot{Q}$ is the heat transfer rate $(\mathrm{kW})$. The subscript numbers indicate the state of the fluids. 


\subsubsection{The Expander}

The power generation in the expander was estimated as:

$$
\dot{W}_{\text {exp }}=\eta_{\text {turbine }} \dot{m}_{W F}\left(h_{1}-h_{2 s}\right)
$$

where $\dot{W}$ is the power $(\mathrm{kW}), \dot{m}$ is the flow rate $(\mathrm{kg} / \mathrm{s}), h$ is the enthalpy $(\mathrm{kJ} / \mathrm{kg})$, and $\eta$ is the efficiency. The subscript numbers indicate the state of the working fluid (s refers to isentropic).

\subsubsection{The ACC}

The ACC condensed vapour from the expander by forcing air over the finned tube. The heat balance between R245fa, and the cooling air is represented in Equation 5. A pinch point temperature difference of $15^{\circ} \mathrm{C}$, a typical value recommended by researchers for a liquid to vapour heat exchanger, was applied to the ACC as shown in Equations 6 and 7.

$$
\begin{gathered}
\dot{m}_{\text {air }} C_{p_{-} \text {air }}\left(T_{\text {air_in }}-T_{\text {air_out }}\right)=\dot{m}_{W F}\left(h_{2}-h_{5}\right) \\
\Delta T_{p p_{-} \text {cond }}=T_{\text {sat_liquid }}-T_{p p_{-} \text {cond }} \\
T_{p p_{-} \text {cond }}=\left(\frac{T_{\text {air_out }}-T_{\text {air_in }}}{\dot{Q}_{\text {air }}}\right)\left[\dot{m}_{W F}\left(h_{3}-h_{5}\right)\right]+T_{\text {air }} \text { in }
\end{gathered}
$$

where $\dot{m}$ is the mass flow rate $(\mathrm{kg} / \mathrm{s}), C_{p}$ is the specific heat capacity $(\mathrm{kJ} / \mathrm{kg} \cdot \mathrm{K}), T$ is the temperature $\left({ }^{\circ} \mathrm{C}\right), h$ is the enthalpy $(\mathrm{kJ} / \mathrm{kg}), \Delta T_{p p}$ is the pinch point difference $\left({ }^{\circ} \mathrm{C}\right), T_{p \mathrm{p}}$ is the pinch point temperature $\left({ }^{\circ} \mathrm{C}\right)$, and $\dot{Q}$ is the heat transfer rate $(\mathrm{kW})$. The subscript numbers indicate the state of fluids.

\subsubsection{Feed Pump}

The power consumption in the feed pump is expressed as:

$$
\dot{W}_{\text {feed pump }}=\frac{\dot{m}_{W F}\left(h_{6}-h_{5}\right)}{\eta_{\text {feed motor }}}
$$

where $\dot{W}$ is the power $(\mathrm{kW}), \dot{m}$ is the mass flow rate $(\mathrm{kg} / \mathrm{s}), h$ is the enthalpy $(\mathrm{kJ} / \mathrm{kg})$, and $\eta$ is the efficiency. The subscript numbers indicate the state of the working fluid.

\subsubsection{The ORC Performance}

The electric power produced by the thermodynamic cycle was determined as:

$$
\dot{W}_{\text {cycle }}=\dot{W}_{\text {exp }}-\dot{W}_{\text {feed pump }}
$$

The electrical energy consumed by the oil pump was predicted as:

$$
\dot{W}_{\text {oil }}=\frac{\dot{m} \Delta P V}{\eta_{\text {pump }} \eta_{\text {motor }}} \times 10^{-3}
$$

where $\dot{m}$ is the flow rate $(\mathrm{kg} / \mathrm{s}), \Delta P$ is the pressure difference $(\mathrm{Pa}), V$ is the specific volume $\left(\mathrm{m}^{3} / \mathrm{kg}\right)$, $\eta_{\text {pump }}$ and $\eta_{\text {motor }}$ are the efficiencies of the pump and motor, respectively.

Therefore, the net electric power and the gross efficiency of the ORC system were respectively calculated as:

$$
\begin{gathered}
\dot{W}_{\text {net }}=\dot{W}_{\text {exp }}-\dot{W}_{\text {loss }}-\dot{W}_{\text {pump }} \\
\eta_{\text {plant }}=\frac{\dot{W}_{\text {net }}}{\dot{Q}_{W F_{-} \text {eva }}}
\end{gathered}
$$

Equations 1 to 12 were then solved with the following assumptions:

- The system is under steady flow.

- The isentropic efficiencies of the expander and pump are $80 \%$ and $70 \%$, respectively.

- The efficiency of the motors is $70 \%$.

- $\quad$ The ambient temperature is $30^{\circ} \mathrm{C}$.

For simulations of the solar ORC, a computer simulation code was made using the Engineering Equations Solver (EES) software [19]. A graphical user interface was set up for convenient simulations, and a sample screenshot of the graphical interface is presented in Figure 2. 


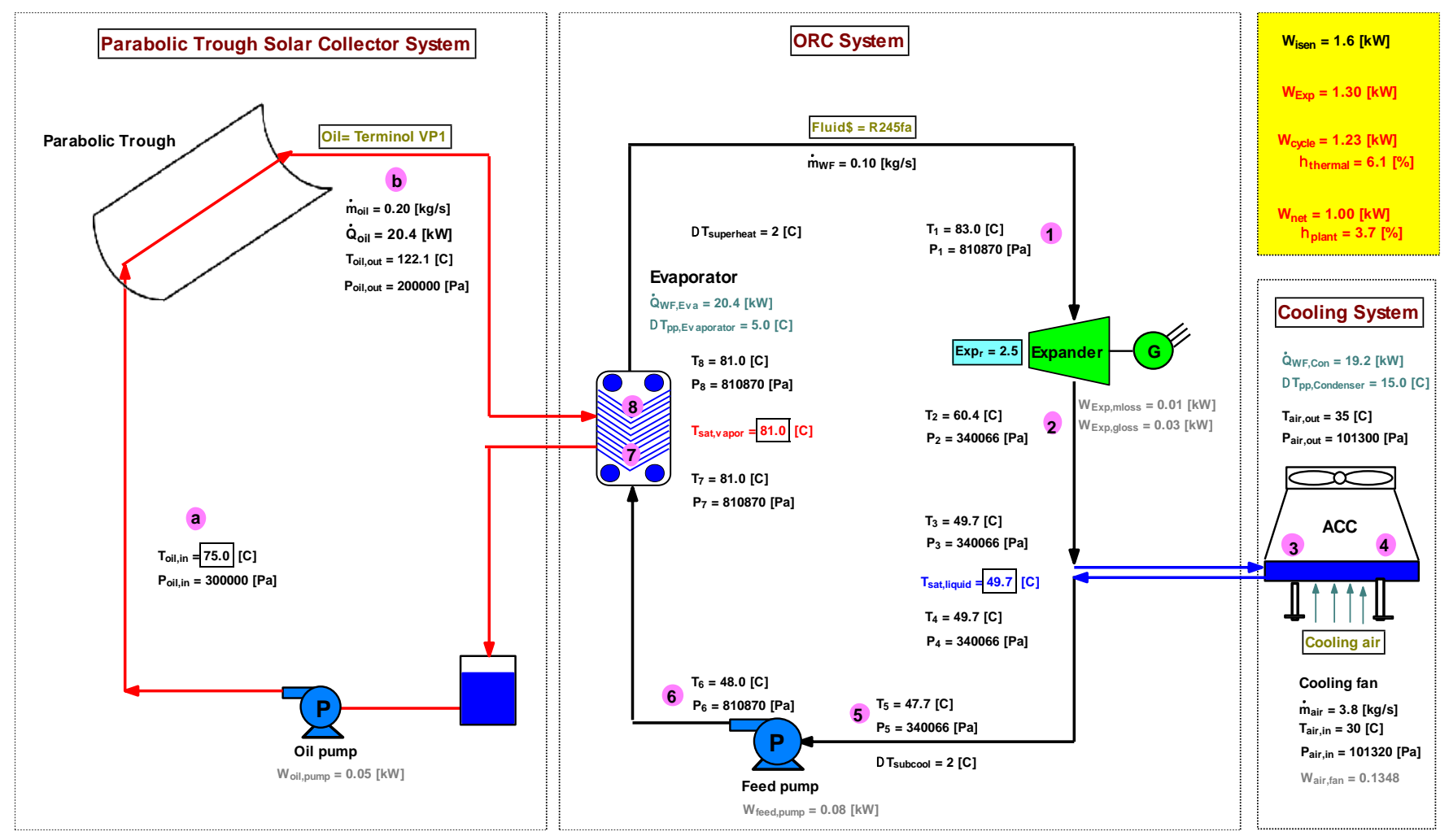

Figure 2 A screenshot of computer simulation of the solar ORC system

\subsection{The PTC}

The main components of the PTC were a parabolic trough reflector, and a heat collector element (HCE) (or receiver tube). The HCE placed at the focal point of the PTC consisted of an absorber pipe, normally a stainless-steel tube, and a Pyrex glass tube coated with selective coating on its surface that enclosed the absorber pipe to enhance the performance of the PTC. The selective coating with low emittance is suggested to reduce the thermal radiation loss, and achieve high efficiency in absorbing solar radiation.

Incoming solar irradiation impinged the parabolic reflector, and then the light rays were reflected to the receiver tube enclosed by the glass envelope. Figure 3 shows the heat transfer processes involved in the HCE. The effective incoming solar energy after considering the optical loss, $\dot{q}_{5-a b s o r b}$ was absorbed by the glass envelope, and the selective coating of absorber tube, $\dot{q}_{3-a b s o r b}$. Most of the energy $\dot{q}_{3-a b s o r b}$ was transferred through the absorber pipe by conduction ( $\left.\dot{q}_{23 \text { cond }}\right)$, and absorbed by the HTF by convection $\left(\dot{q}_{12 \text { conv }}\right)$. Part of the energy $\dot{q}_{3-a b s o r b}$ was reflected to the glass envelope by convection $\left(\dot{q}_{34 c o n v}\right)$ and radiation $\left(\dot{q}_{34 \mathrm{rad}}\right)$. The reflected heat $\dot{q}_{34 c o n v}$ and $\dot{q}_{34 \mathrm{rad}}$ was transferred through the glass enveloped by conduction $\left(\dot{q}_{45 \text { cond }}\right)$ and then discharged to ambient air by convection $\left(\dot{q}_{56 \mathrm{cov}}\right)$, and to the sky by radiation $\left(\dot{q}_{57 \mathrm{rad}}\right)$. The effective optical efficiency was determined by the imperfection of the solar collector ensembles, and the factors affecting the optical efficiency listed in Table 1 as summarized by Forristall [15] based on the report by Price [20] from NREL. The heat transfer relations in the HCE are presented in Table 2 [15].

The solar incidence angle is not always normal to the collector aperture in real conditions, as changes in refraction and reflection are affected by the position of the sun, trough end shading and selective coating incident angle effects. Therefore, incident angle modifier (K) factor (Equation 13) was included in this model where solar irradiation was not $90^{\circ}$ to the aperture [15].

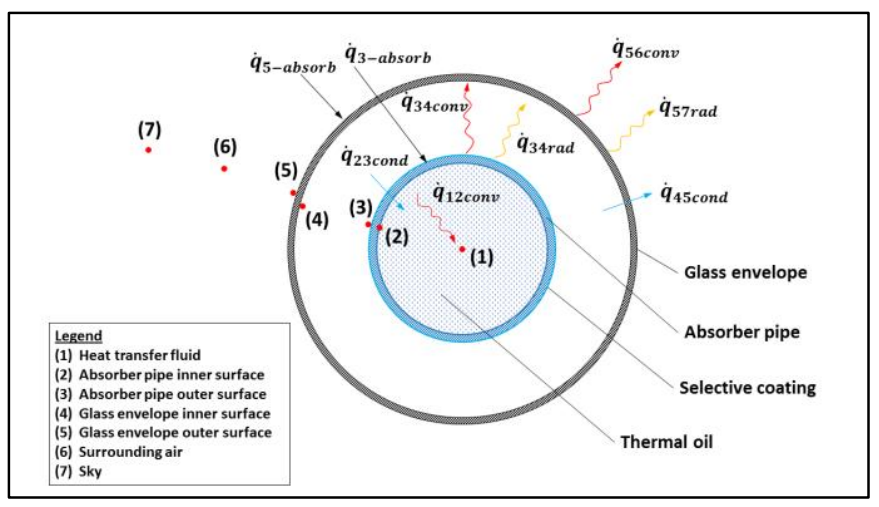

Figure 3 Heat transfer processes in the HCE 
Table 1 Terms of effective optical efficiency [15]

\begin{tabular}{ll}
\hline \multicolumn{1}{c}{ Term } & Efficiency \\
\hline HCE shadowing (bellows, shielding, supports) & 0.974 \\
Tracking Error & 0.994 \\
Geometry Error (mirror alignment) & 0.98 \\
Clean Mirror Reflectance & 0.935 \\
Dirt on Mirrors & 0.90 \\
Dirt on HCE & $(1+0.90) / 2$ \\
Unaccounted & 0.96 \\
\hline
\end{tabular}

$$
K=\cos \theta+0.000884 \theta-0.00005369 \theta^{2}
$$

Heat transfer was treated as heat flux because solar irradiation absorption by the absorber occurred close to the surface. Therefore, solar absorption by the collector $\left(\dot{q}_{3-a b s o r b}\right)$, and by glass tube $\left(\dot{q}_{5-a b s o r b}\right)$ were given by [15]:

$$
\begin{aligned}
& \dot{q}_{3-a b s o r b}=\dot{q}_{s i} \eta_{a b s} \alpha_{a b s} \\
& \dot{q}_{5-a b s o r b}=\dot{q}_{s i} \eta_{e n v} \alpha_{e n v}
\end{aligned}
$$

where $\dot{q}_{s i}$ is the solar irradiation, $\eta$ is the efficiency, and $\alpha$ is the absorptivity.

The following energy balance equations were applied to solve heat transfer equations in the $\mathrm{HCE}$ (see Table 2):

$$
\begin{gathered}
\dot{q}_{12 \text { conv }}=\dot{q}_{23 \text { cond }} \\
\dot{q}_{3-\text { absorb }}=\dot{q}_{34 \text { conv }}+\dot{q}_{34 \mathrm{rad}}+\dot{q}_{23 \mathrm{cond}} \\
+\dot{q}_{\text {bracket }, \text { cond }} \\
\dot{q}_{34 \mathrm{conv}}+\dot{q}_{34 \mathrm{rad}}=\dot{q}_{45 \mathrm{cond}} \\
\dot{q}_{45 \mathrm{cond}}+\dot{q}_{5-\text { absorb }}=\dot{q}_{56 \mathrm{conv}}+\dot{q}_{57 \mathrm{rad}}
\end{gathered}
$$

The optical properties for the different type of selective coatings are summarized in Tables 3 and 4 [15]. Input parameters for simulation of the PTC are listed in Table 5. Forristall's model [15] was mainly modified to set up a model of the PTC for the purpose of this study, and then the PTC model was fully integrated with the ORC model for streamlined simulations to support a complete design process of a solar ORC. The following assumptions were used for simplification of the PTC model:

- The heat transfer is one dimensional.

- All temperatures and heat fluxes are uniform.

\begin{tabular}{|c|c|c|c|}
\hline & Heat transfer & Heat transfer relation & Notes \\
\hline $1-2$ & Convection & $\dot{q}_{12 \text { conv }}=\pi D_{2} h_{1}\left(T_{2}-T_{1}\right)$ & \\
\hline $2-3$ & Conduction & $\dot{q}_{23 \text { cond }}=2 \pi K_{23} \frac{T_{3}-T_{2}}{\ln \frac{D_{3}}{D_{2}}}$ & \\
\hline \multirow[t]{4}{*}{$3-4$} & Convection & $\dot{q}_{34 \text { conv }}=\pi D_{3} h_{34}\left(T_{3}-T_{4}\right)$ & For $P<1.0$ Torr \\
\hline & Convection & $2.425 k_{34}\left(T_{3}-T_{4}\right)\left[\frac{\operatorname{Pr} R a_{D 3}}{\sin }\right]$ & \\
\hline & & $\dot{q}_{34 \text { conv }}=\frac{\left[\left(0.861+P r_{34}\right)^{\overline{4}}\right]}{\left[1+\left(\frac{D_{3}}{D_{4}}\right)^{\frac{3}{5}}\right]^{\frac{5}{4}}}$ & For $\mathrm{P}>1.0$ Torr \\
\hline & Radiation & $\dot{q}_{34 \mathrm{rad}}=\frac{\sigma \pi D_{3}}{\frac{1}{\varepsilon_{3}}+\frac{D_{3}}{D_{4}}\left(\frac{1-\varepsilon_{4}}{\varepsilon_{4}}\right)}\left(T_{3}^{4}-T_{4}^{4}\right)$ & \\
\hline $4-5$ & Conduction & $\dot{q}_{45 \text { cond }}=2 \pi k_{45} \frac{T_{4}-T_{5}}{\ln \frac{D_{5}}{D_{4}}}$ & \\
\hline $5-6$ & Convection & $\dot{q}_{56 \mathrm{conv}}=\pi D_{5} h_{56}\left(T_{5}-T_{6}\right)$ & \\
\hline $5-7$ & Radiation & $\dot{\mathrm{q}}_{57 \mathrm{rad}}=\sigma \pi D_{5} \varepsilon_{5}\left(T_{5}^{4}-T_{7}^{4}\right)$ & \\
\hline
\end{tabular}

- $\quad$ Steady state flow in the PTC.

- Constant thermal conduction.

- Constant convective heat coefficient.

A graphical user interface for the PTC was set up using EES to help simulations, and a sample screenshot is presented in Figure 4.

Table 2 Heat transfer relations in the PCT 
Table 3 Properties of selective coatings

\begin{tabular}{lcc}
\hline \multicolumn{1}{c}{ Selective coating } & $\begin{array}{c}\text { Glass envelope } \\
\text { transmittance }\end{array}$ & $\begin{array}{c}\text { Selective } \\
\text { coating } \\
\text { absorption }\end{array}$ \\
\hline Black Chrome & 0.935 & 0.940 \\
Luz Cermet & 0.935 & 0.920 \\
Solel UVAC Cermet Test a & 0.965 & 0.960 \\
Solel UVAC & 0.965 & 0.950 \\
Cermet Test b & 0.965 & 0.955 \\
Solel UVAC \\
Cermet Avverage & 0.960 & 0.950 \\
Schott PTR $\AA 70$ & & \\
\hline
\end{tabular}

Table 4 Coating emittance of selective coatings

\begin{tabular}{|c|c|}
\hline Selective coating & Coating emittance \\
\hline Black Chrome & $0.0005333\left(T_{3}+273.15-0.0856\right)$ \\
\hline Luz Cermet & $0.000327\left(T_{3}+273.15-0.065971\right)$ \\
\hline $\begin{array}{l}\text { Solel UVAC Cermet } \\
\text { Test a }\end{array}$ & $\begin{aligned} 2.249 \times 10^{-7}\left(T_{3}\right)^{2}+ & 1.039 \times 10^{-4} T_{3} \\
+ & 5.599 \times 10^{-2}\end{aligned}$ \\
\hline $\begin{array}{l}\text { Solel UVAC Cermet } \\
\text { Test b }\end{array}$ & $\begin{aligned} 1.565 \times 10^{-7}\left(T_{3}\right)^{2}+ & 1.376 \times 10^{-4} T_{3} \\
+ & 6.966 \times 10^{-2}\end{aligned}$ \\
\hline $\begin{array}{l}\text { Solel UVAC Cermet } \\
\text { Avg }\end{array}$ & $\begin{aligned} 1.907 \times 10^{-7}\left(T_{3}\right)^{2}+ & 1.208 \times 10^{-4} T_{3} \\
+ & +6.282 \times 10^{-2}\end{aligned}$ \\
\hline Schott PTR $® 70$ & $2.00 \times 10^{-7} T_{3}+0.062$ \\
\hline
\end{tabular}

Table 5 Input parameters for PTC simulations

\begin{tabular}{ll}
\hline \multicolumn{1}{c}{ Parameter } & Value \\
\hline Global solar irradiance, $I_{b}$ & $1367.0 \mathrm{~W} / \mathrm{m}^{2}$ \\
Glass absorptance (Pyrex), $\alpha_{\text {env }}$ & 0.02 \\
Emissivity of inner glass envelope, $\varepsilon 4$ & 0.86 \\
Emissivity of outer envelope, $\varepsilon 5$ & 0.86 \\
Wind speed, $V_{6}$ & $1.0 \mathrm{mph}$ \\
Volumetric flow rate of oil, $V_{1}$ & $0.0002 \mathrm{~m}^{3} / \mathrm{s}$ \\
Heat transfer rate of oil, $\dot{Q}_{\text {oil }}$ & $20.4 \mathrm{~kW}$ \\
Inlet oil temperature, $T_{\text {oil_in }}$ & 75.0 \\
Outlet oil temperature, $T_{\text {oil_out }}$ & 122.2 \\
HTF temperature, $T_{1 \text { ave }}$ & 98.6 \\
Ambient temperature, $T_{6}$ & 30.0 \\
Incident angle, $\theta$ & 30.0 \\
Ambient Pressure, $P_{6}$ & $0.83 \mathrm{~atm}$ \\
Annulus gas pressure, $P_{a}$ & $0.90 \mathrm{~atm}$ \\
Reflectivity of mirror & 0.9 \\
Stefan-Boltzmann, $\sigma$ & $5.67 \times 10^{-8} \mathrm{~W} / \mathrm{m}^{2} . \mathrm{K}^{4}$ \\
Gravitational acceleration & $9.81 \mathrm{~m} 2 / \mathrm{s}$ \\
\hline
\end{tabular}

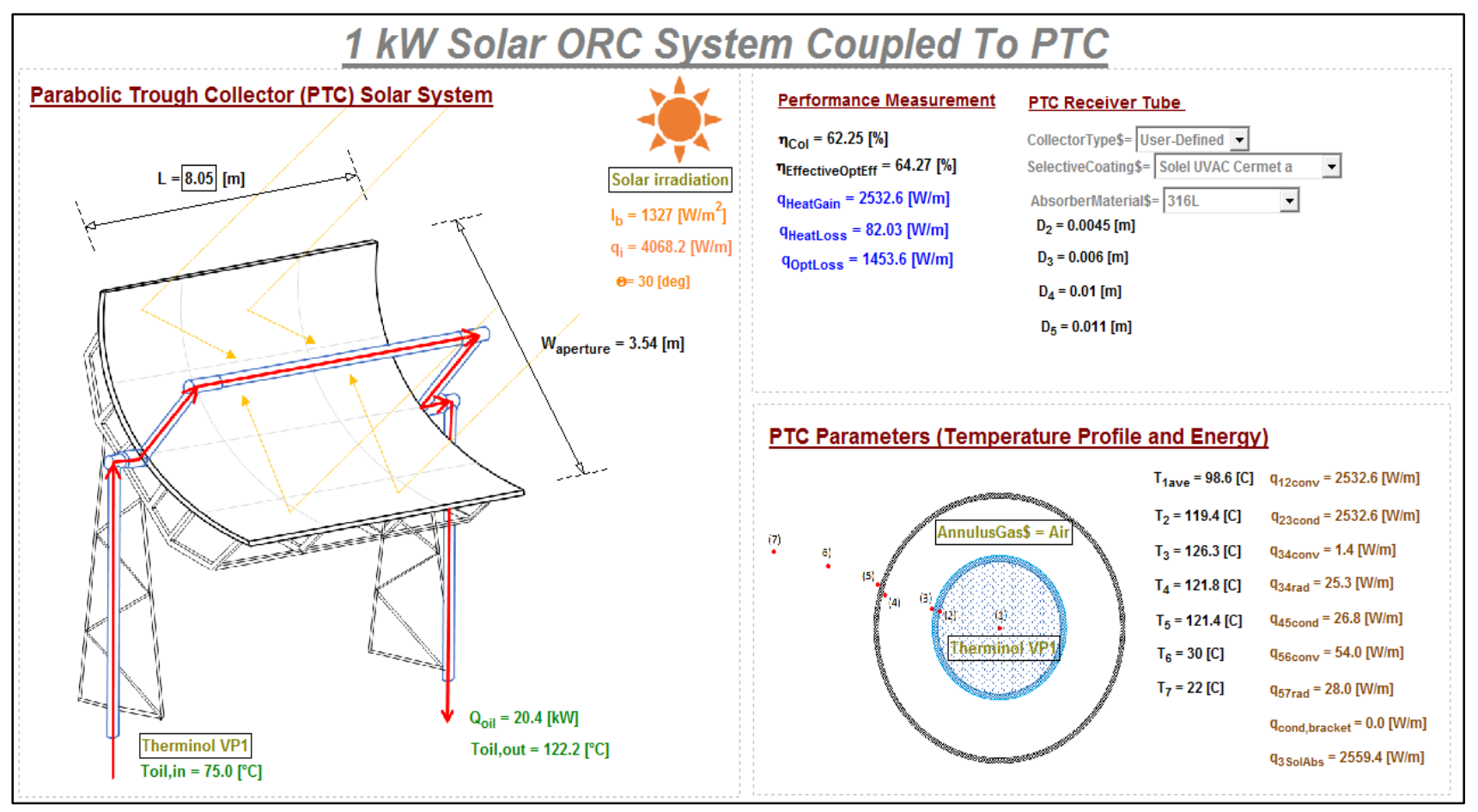

Figure 4 A screenshot of computer simulation for the PTC

\subsection{SIMULATION RESULTS AND DISCUSSION}

\subsection{The Solar ORC}

Simulations of the ORC were carried out to determine the operating conditions and performance of the ORC, and the design requirements of the PTC. The temperature-heat transfer ( $T-Q$ ) diagram examined the evaporator and condenser to ensure that the
ORC design meets the pinch point temperature differences required (see Figure 5). The simulation results of the ORC that generated electric power of 1 $\mathrm{kW}_{\mathrm{e}}$ are listed in Table 6 . The thermal efficiency of the ORC was $6.1 \%$, and the overall plant efficiency was $3.7 \%$. The solar thermal energy required was $20.4 \mathrm{~kW}$, the flow rate of the thermal oil was $0.2 \mathrm{~kg} / \mathrm{s}$, and the oil temperatures at the inlet and outlet of the HCE were $75.0^{\circ} \mathrm{C}$ and $122.2^{\circ} \mathrm{C}$, respectively. 


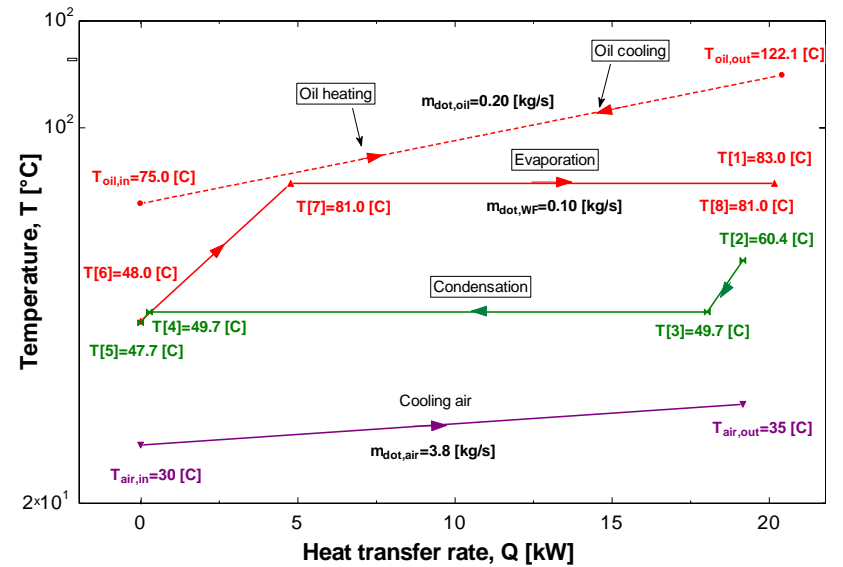

Figure $5 \mathrm{~T}-\mathrm{Q}$ diagram for the heat exchangers

\subsection{The PTC}

This section presents the process for sizing PTC for the $1 \mathrm{~kW}_{\mathrm{e}}$ solar ORC. First, the selections of the absorber tube material and tube coating are described. Next, the PTC sizing is conducted with selected tube. Then, the PTC performance is examined using the selected PTC for different oil flow rates.

\subsubsection{Selection of Absorber Tube Material}

Three different types of low cost absorber tube materials were evaluated to select the best absorber type for the HCE. The selected materials were stainless-steel (SS) 304L, 321 H, and B42 copper. The tube specifications adopted in the simulations are shown in Table 7. The performance of the absorber tube materials in the solar energy collector is shown in Figure 6. It was observed that the collector efficiency decreased with the increase of the oil temperature, with the efficiency changing between $41 \%$ and $49 \%$ for the oil temperatures under investigation.

Table 6 Simulation results of the $1 \mathrm{KWe}$ solar ORC

\begin{tabular}{ll}
\multicolumn{1}{c}{ Parameter } & Value \\
\hline HTF rate at ACC, $\dot{Q}_{W F, \text { Con }}$ & $19.2 \mathrm{~kW}$ \\
HTF rate at evaporator, $\dot{Q}_{W F, E v a}$ & $20.4 \mathrm{~kW}$ \\
Heat transfer rate of oil, $\dot{Q}_{\text {oil }}$ & $20.4 \mathrm{~kW}$ \\
Mass flow rate of R245fa, $\dot{m}_{W F}$ & $0.1 \mathrm{~kg} / \mathrm{s}$ \\
Mass flow rate of cooling air, $\dot{m}_{\text {air }}$ & $3.8 \mathrm{~kg} / \mathrm{s}$ \\
Mass flow rate of oil, $\dot{m}_{\text {oil }}$ & $0.2 \mathrm{~kg} / \mathrm{s}$ \\
Expander ratio, $E x p_{r}$ & 2.5 \\
Inlet pressure of expander, $P_{1}$ & $810870 \mathrm{~Pa}$ \\
Outlet pressure of expander, $P_{2}$ & $340066 \mathrm{~Pa}$ \\
Inlet pressure of ACC, $P_{3}$ & $340066 \mathrm{~Pa}$ \\
Outlet pressure of ACC, $P_{4}$ & $340066 \mathrm{~Pa}$ \\
Inlet pressure of feed pump, $P_{5}$ & $340066 \mathrm{~Pa}$ \\
Outlet pressure of feed pump, $P_{6}$ & $810870 \mathrm{~Pa}$ \\
Inlet pressure of evaporator, $P_{7}$ & $810870 \mathrm{~Pa}$ \\
Outlet pressure of evaporator, $P_{8}$ & $810870 \mathrm{~Pa}$ \\
Inlet temperature of expander, $T_{1}$ & $83.0{ }^{\circ} \mathrm{C}$ \\
\hline
\end{tabular}

\begin{tabular}{ll}
\hline \multicolumn{1}{c}{ Parameter } & Value \\
\hline Outlet temperature of expander, $T_{2}$ & $60.4^{\circ} \mathrm{C}$ \\
Inlet temperature of ACC, $T_{3}$ & $49.7{ }^{\circ} \mathrm{C}$ \\
Outlet temperature of ACC, $T_{4}$ & $49.7{ }^{\circ} \mathrm{C}$ \\
Inlet temperature of feed pump, $T_{5}$ & $47.7^{\circ} \mathrm{C}$ \\
Outlet temperature of feed pump, $T_{6}$ & $48.0^{\circ} \mathrm{C}$ \\
Inlet temperature of evaporator, $T_{7}$ & $81.0^{\circ} \mathrm{C}$ \\
Outlet temperature of evaporator, $T_{8}$ & $81.0^{\circ} \mathrm{C}$ \\
Inlet temperature of PTC, $T_{\text {oil,in }}$ & $75.0^{\circ} \mathrm{C}$ \\
Outlet temperature of PTC, $T_{\text {oil,out }}$ & $122.2^{\circ} \mathrm{C}$ \\
Saturated liquid temperature & $49.7{ }^{\circ} \mathrm{C}$ \\
Saturated vapour temperature & $81.0{ }^{\circ} \mathrm{C}$ \\
Total electricity recovered, $\dot{W}_{\text {isen }}$ & $1.60 \mathrm{~kW}$ \\
Output power of expander, $\dot{W}_{\text {exp }}$ & $1.30 \mathrm{~kW}$ \\
Power generated by ORC, $\dot{W}_{\text {cycle }}$ & $1.23 \mathrm{~kW}$ \\
Net power production by plant, $\dot{W}_{\text {net }}$ & $1.0 \mathrm{~kW}$ \\
ORC thermal efficiency, $\eta_{\text {thermal }}$ & $6.1 \%$ \\
Efficiency of power plant, $\eta_{\text {plant }}$ & $3.7 \%$
\end{tabular}

The reduction in efficiency against oil temperature can be explained by the fact that the heat loss rises with increasing oil temperature. The graphs for $304 \mathrm{~L}$ and $321 \mathrm{H}$ overlapped due to the almost negligible differences between the two materials. SS $316 \mathrm{~L}$ was chosen as the absorber tube base material since it has an excellent toughness and good oxidation resistance in applications up to $870^{\circ} \mathrm{C}$. Forristall [15] reported that 316L remains a good candidate for fabrication of HCE in terms of cost and its strength in heat transfer application.

Table 7 Simulation conditions for selection of tube material

\begin{tabular}{ll}
\hline \multicolumn{1}{c}{ Parameter } & \multicolumn{1}{c}{ Value } \\
\hline Selective coating & Black Chrome \\
Absorber pipe inner diameter & $0.066 \mathrm{~m}$ \\
Absorber pipe outer diameter & $0.070 \mathrm{~m}$ \\
Inner diameter of glass tube & $0.109 \mathrm{~m}$ \\
Outer diameter of glass tube & $0.115 \mathrm{~m}$ \\
Aperture length & $4.4235 \mathrm{~m}$ \\
Wind speed & $1.0 \mathrm{mph}$ \\
Volumetric flow rate of oil & $0.02 \mathrm{~m}^{3} / \mathrm{s}$ \\
Ambient temperature & $35^{\circ} \mathrm{C}$ \\
Incident angle & $30^{\circ}$ \\
\hline
\end{tabular}

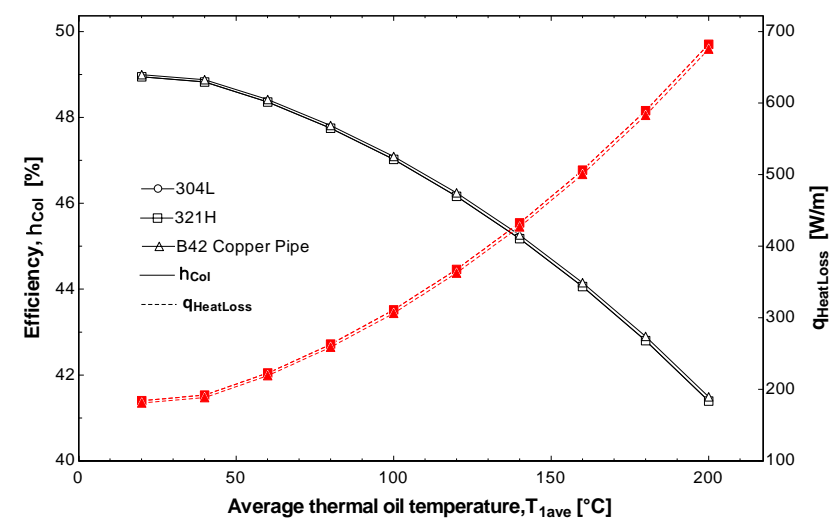

Figure $\mathbf{6}$ Variations of the collector efficiency and the heat loss with the oil temperature for three absorber materials 


\subsubsection{Selection of Selective Coatings}

Six different types of selective coatings (as listed in Table 3) were examined to select a coating that produces the highest collector efficiency when applied to the absorber tube. Figure 7 shows the variation in the efficiency of the collectors with different coatings against oil temperature. It was observed that, of the six coatings, the absorber tube with Solel UVAC Cermet Test a coating; yielded the highest collector efficiency. This can be explained by the fact that the Solel UVAC Cermet Test a coating, has the highest absorptance for radiation in the solar energy spectrum (refer to Table 3 ). In addition, the coating may have lower coating emittance than other coating types, thus reducing the thermal radiation loss to the surrounding in the operating condition. It was also noted that the efficiency of the coating was between $44 \%$ and $51.5 \%$ higher than the collector without coating that varied from $41 \%$ to $49 \%$. Luz Cermet showed the lowest collector efficiency of the coating types under investigation. Therefore, it is proposed that Solel UVAC Cermet Test a, be selected as the coating type.

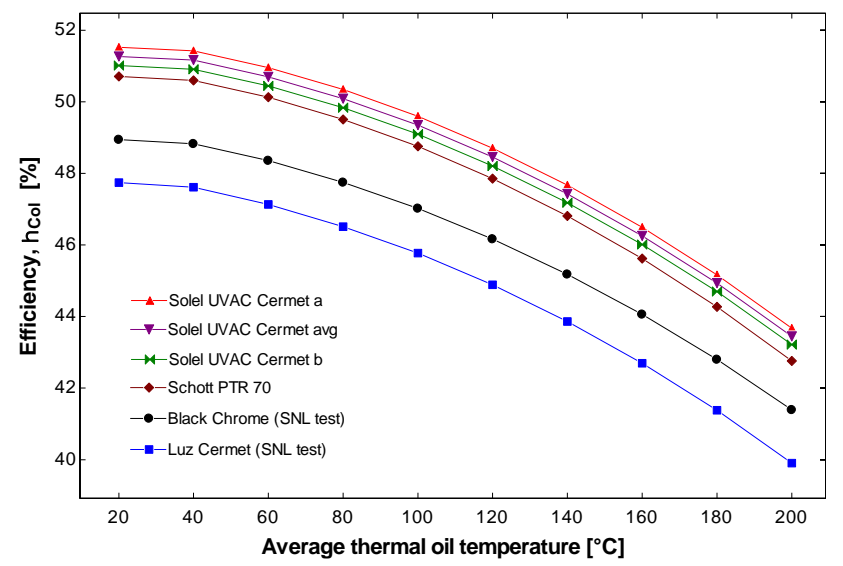

Figure $\mathbf{7}$ Variation of the collector efficiency with average oil temperature for six different coatings

\subsubsection{Sizing of the PTC}

In order to determine the size of PTC suitable for the 1 $\mathrm{kW}_{\mathrm{e}}$ solar ORC, simulations were performed with the seven different HCE dimensions listed in Table 8. The size of the absorber tube was adopted from reference [21]. Pyrex Borosilicate glass tubing was selected as the envelope of the absorber tube due to its high strength and favourable radiation properties under high temperature [22]. As identified in the previous sections, SS316L and Solel UVAC Cermet Test a, were respectively employed as tube material and coating.

The variations of the collector efficiency and the heat gain for the seven HCE cases are depicted in Figure 8 with respect to the Reynolds number. It was observed that the efficiency and heat gain increased as the Reynolds number increased, with
Case 1 presenting the highest performance. Case 1 has the smallest inner diameter of absorber tube so the oil velocity in the tube was greatest, and the flow became more turbulent. This simulation result has a good agreement with the study by Vahidinia and Miri [23] where they reported that the thermal performance in turbulent pipe flow rises with increasing Reynolds number since the heat transfer coefficient increases with the increase of the Reynolds number. Therefore, it is determined that the HCE size of Case 1 is appropriate for the PTC. For Case 1, the length of the tube and the aperture width of the PTC are estimated to be $8.05 \mathrm{~m}$ and 3.54 $m$, respectively.

Table 8 Seven different HCE dimensions for simulation

\begin{tabular}{cccccccc}
\hline Case & $\mathbf{1}$ & $\mathbf{2}$ & $\mathbf{3}$ & $\mathbf{4}$ & $\mathbf{5}$ & $\mathbf{6}$ & $\mathbf{7}$ \\
\hline$D_{2}(\mathrm{~mm})$ & 4.5 & 6.5 & 8.5 & 10.5 & 14.5 & 16.5 & 18.0 \\
$D_{3}(\mathrm{~mm})$ & 6.0 & 8.0 & 10.0 & 12.0 & 16.0 & 18.0 & 20.0 \\
$D_{4}(\mathrm{~mm})$ & 10.0 & 11.8 & 13.8 & 15.8 & 18.8 & 20.5 & 23.5 \\
$D_{5}(\mathrm{~mm})$ & 11.0 & 13.0 & 15.0 & 17.0 & 20.0 & 22.0 & 25.0
\end{tabular}

$D_{2}$ : Inner diameter of absorber tube

$D_{3}$ : Outer diameter of absorber tube

$D_{4}$ : Inner diameter of glass envelope

$D_{5}$ : Outer diameter of glass envelope

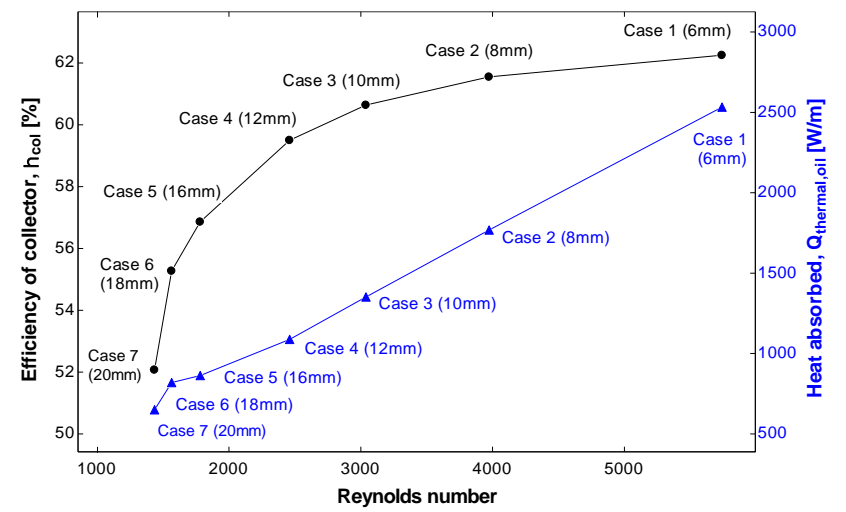

Figure 8 Variations of the collector efficiency and the heat gain with the Reynolds number for the seven cases

\subsubsection{Effects of Flow Rate on PTC Performance}

With the selected HCE dimension (Case 1), the variation of heat gain in the collector was examined against the average oil temperature for five different flow rates, and the results are illustrated in Figure 9. It was observed that the heat gain increased with the increase of the oil flow rate, with the differences of the heat gain being negligible in the flow rates ranging from $0.6 \mathrm{~kg} / \mathrm{s}$ to $1.0 \mathrm{~kg} / \mathrm{s}$. The heat gain reduced as the oil temperature increased. It could be explained by the fact that higher temperature yields higher heat loss by radiation. 


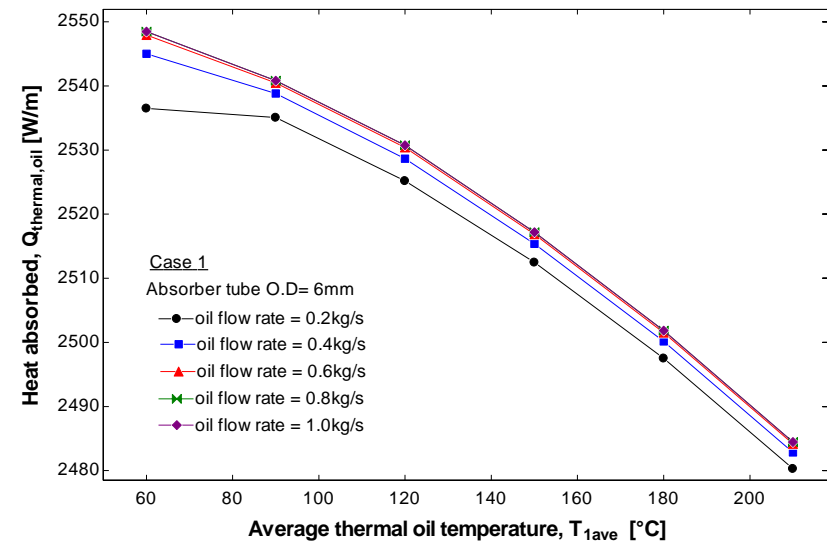

Figure 9 Variation of the heat gain in the selected collector (Case 1) with the average oil temperature

\subsection{CONCLUSIONS}

PTC is a type of collector for solar thermal energy. In this study, PTC was numerically investigated and a PTC suitable for a $1 \mathrm{kWe}$ solar ORC was selected. Design requirements for the PTC were obtained by thermodynamic analysis of the ORC: the solar thermal energy required is $20.4 \mathrm{~kW}$; the flow rate of the thermal oil is $0.2 \mathrm{~kg} / \mathrm{s}$; and the oil temperatures at the inlet and outlet of the HCE are $75.0^{\circ} \mathrm{C}$ and $122.2^{\circ} \mathrm{C}$, respectively. It was found that SS $316 \mathrm{~L}$ is appropriate for the absorber tube material of the materials under investigation. For tube coating, the Solel UVAC Cermet Test a coating was selected, with the highest collector efficiency being $62.25 \%$ of the selective coatings from literature. Seven cases of HCE dimensions were examined, and it was identified that the collector efficiency was greatest with an inner diameter of $4.5 \mathrm{~mm}$, and an outer diameter of 6.0 $\mathrm{mm}$. It was found that the Reynolds number and flow rate of oil have a significant impact on the performance of the PTC. The efficiency of the PTC rises with the increase of the Reynolds number and flow rate. The length of the receiver and width of the aperture were determined to be $8.05 \mathrm{~m}$ and $3.54 \mathrm{~m}$, respectively. Further study is recommended to select a thermal storage system for night-time operation of the ORC.

\section{Acknowledgement}

This work is based on the research supported in part by FRGS grant, FRGS/1/2015/TK07/CURTIN/03/1. The authors fully acknowledge and appreciate the support received from the Ministry of Higher Education of Malaysia and Curtin University Malaysia.

\section{References}

[1] Ecotricity. The End of Fossil Fuels. https://www.ecotricity.co.uk/our-green-energy/energyindependence/the-end-of-fossil-fuels (accessed December 6, 2017).

[2] Mills, D. 2004. Advances in Solar Thermal Electricity Technology. Solar Energy. 76(1-3): 19-31. DOI: https://doi.org/10.1016/S0038-092X(03)00102-6.

[3] He, Y. L., Mei, D. H., Yang, W. W. and Liu, H. L. 2012 Simulation of the Parabolic Trough Solar Energy Generation System with Organic Rankine Cycle. Applied Energy. 97: 630-641. DOI: https://doi.org/10.1016/j.apenergy.2012.02.047.

[4] Desai, N. B. and S. Bandyopadhyay, S. 2016. Thermoeconomic Analysis and Selection of Working Fluid for Solar Organic Rankine Cycle. Applied Thermal Engineering. 95: 471-481.

DOI: https://doi.org/10.1016/j.applthermaleng.2015.11.018.

[5] Usman, M., Imran, M., Yang, Y., Lee, D. H. and Park, B. S. 2017. Thermo-economic Comparison of Air-cooled and Cooling Tower Based Organic Rankine Cycle (ORC) with R245fa and R1233zde as Candidate Working Fluids for Different Geographical Climate Conditions. Energy. 123: 353-366.

DOI: https://doi.org/10.1016/j.energy.2017.01.134.

[6] Quoilin, S., Orosz, M., Hemond, H. and Lemort, V. 2011. Performance and Design Optimization of a Low-cost Solar Organic Rankine Cycle for Remote Power Generation. Solar Energy. 85(5): 955-966. DOI: https://doi.org/10.1016/j.solener.2011.02.010.

[7] Sait, H. H., Martinex-Val, J., Abbas, R. and Munoz-Anton, J. 2015. Fresnel-based Modular Solar Fields for Performance/Cost Optimization in Solar Thermal Power Plants: A Comparison with Parabolic Trough Collectors. Applied Energy. 141: 175-189. DOI: https://doi.org/10.1016/j.apenergy.2014.11.074.

[8] Wang, J., Yan, Z., Zhao, P. and Dai, Y. 2014. Off-design Performance Analysis of a Solar-powered Organic Rankine Cycle. Energy Conversion and Management. 80: 150-157.

DOI: https://doi.org/10.1016/j.enconman.2014.01.032.

[9] Orosz, M., Mueller, A., Quoilin, S. and Hemond, H. 2009. Small Scale Solar ORC system for Distributed Power. Proceedings of SolarPACES, 2009.

[10] Pikra, G., Salim, A., Prawara, B., Purwanto, A. J. and Admono, T. 2013. Development of Small Scale Concentrated Solar Power Plant Using Organic Rankine Cycle for Isolated Region in Indonesia. Energy Procedia. 32: 122-128.

DOI: https://doi.org/10.1016/j.egypro.2013.05.016.

[11] Taccani, R., Obi, J. B., Lucia, M. D., Micheli, D. and Toniato, G. 2016. Development and Experimental Characterization of a Small Scale Solar Powered Organic Rankine Cycle (ORC). Energy Procedia. 101: 504-511.

[12] Orosz, M., Quoilin, S. and Hemond, H. 2010. SORCE: A Design Tool for Solar Organic Rankine Cycle Systems in Distributed Generation Applications. http://hdl.handle.net/2268/73580.

[13] Cakici, D. M., Erdogan, A. and Colpan, C. O. 2017. Thermodynamic Performance Assessment of an Integrated Geothermal Powered Supercritical Regenerative Organic Rankine Cycle and Parabolic Trough Solar Collectors. Energy. 120: 306-319. DOI: https://doi.org/10.1016/j.energy.2016.11.083.

[14] Borunda, M., Jaramillo, O. A., Dorantes, R. and Reyes, A. 2016. Organic Rankine Cycle Coupling with a Parabolic Trough Solar Power Plant for Cogeneration and Industrial Processes. Renewable Energy. 86: 651-663. DOI:https://doi.org/10.1016/j.renene.2015.08.041.

[15] Forristall, R. 2003. Heat Transfer Analysis and Modeling of a Parabolic Trough Solar Receiver Implemented in 
Engineering Equation Solver. National Renewable Energy Laboratory. Technical Report.

[16] Ghasemi, S. E. and Ranjbar, A. A. 2016. Thermal Performance Analysis of Solar Parabolic Trough Collector Using Nanofluid as Working Fluid: A CFD Modelling Study. Journal of Molecular Liquids. 222: 159-166. DOl: https://doi.org/10.1016/j.molliq.2016.06.091

[17] Sarawak Energy. Alternative Energy for Sarawak-Lighting up off-grid communities. http://www.sarawakenergy.com.my/index.php/newsevents-top/latest-news-events/latestannouncements/1826-alternative-energy-for-sarawaklighting-up-off-grid-communities (accessed December 6, 2017).

[18] Mansor, M. 2014. A Study on Wind and Solar Energy Potentials in Malaysia. International Journal of Renewable Energy Research. 4(4): 1042-1048.

[19] Klein, S. A. 2017. Engineering Equation Solver (V10.093). FChart Software.
[20] Price, H. 2001. Concentrated Solar Power Use in Africa. NREL/TP. Golden, CO: National Renewable Energy Laboratory.

[21] Swagelok, Stainless Steel Seamless Tubing and Tube Support Systems. n.d. https://www.swagelok.com/downloads/webcatalogs/EN/ MS-01-181.PDF (accessed December 6, 2017).

[22] Sci-Tech Glassblowing, Inc. Properties of Corning 7740 Pyrec Glass.n.d. http://www.scitechglassblowing.com/products/listing.asp?idCategory=2 (accessed December 6, 2017).

[23] Vahidinia, F. and Miri, M. 2015. Numerical Study of the Effect of the Reynolds Numbers on Thermal and Hydrodynamic Parameters of Turbulent Flow Mixed Convection Heat Transfer in an Inclined Tube. Journal of Mechanical Engineering. 61(11): 669-679. DOI: http://dx.doi.org/10.5545/sv-jme.2015.2818. 